$\begin{array}{r}\text { Phinisi Integration Review } \\ \text { Vol. 2, No.1, Februari 2019 Hal 020-026 } \\ \text { Website: http://ojs.unm.ac.id/pir } \\ \text { p-ISSN: 2614-2325 dan e-ISSN: 2614-2317 } \\ \hline\end{array}$

\title{
Upacara Mangrara Banua Tongkonan dalam Makna Sosial Masyarakat Tana Toraja
}

\author{
Nur Riswandy Marsuki ${ }^{(1)}$, Lukman Ismail ${ }^{(2)}$, Sam'un Mukramin ${ }^{(3)}$ \\ Program Studi Pendidikan Sosiologi \\ Universitas Muhammadiyah Makassar \\ Jalan Sultan Alauddin/Tala Salapang No. 259 Makassar, 90221 \\ email: $\frac{\text { riswandymarsuki@unismuh.ac.id }}{\text { sam'un.mukramin@ lukmismuh.ac.id }}$
}

\begin{abstract}
Abstrak. Adapaun yang melatar belakangi penelitian ini, karena terdapat ketidaksesuain antara idealis dan realitas. Perubahan sosial yang mengarah ke perubahan negatif yaitu Westernisasi atau perubahan yang mengarah pada kehancuran budaya. tapi pada kenyataannya masih banyak budaya yang dipertahankan sampai sekarang ini. Dalam hal ini peneliti akan mengkaji budaya lokal yang sampai saat ini masih dilestarikan. Misalnya Upacara Mangrara Banua Tongkonan, penulis dapat melihat bahwa hanya sebagian besar saja generasi muda masyarakat Tanah Toraja yang tahu secara spesifik makna-makna dari Upacara Mangrara banua Tongkonan. Jenis penelitian yang digunakan adalah Penelitian deskriptif kualitatif yaitu jenis penelitian yang suatu metode dalam meneliti status kelompok manusia, suatu objek, suatu peristiwa. Lokasi penelitian ini dilakukan di Kelurahan Ariang Kecamatan Makale Kabupaten Tana Toraja, dengan teknik pengumpulan data yang digunakan yaitu observasi dan wawncara dengan informan. Hasil penelitian yang diperoleh mengenai makna sosial Upacara Mangrara Banua Tongkonan di Tana Toraja yang dianalisis secara deskriptif kualitatif, maka dapat disimpulkan bahwa penyebab Upacara Mangrara Banua Tongkonan masih dilestarikan sampai sekarang karena adanya nilai, tradisi dan partisipasi aktif masyarakat. Sedangkan Makna yang terkandung dalam Upacara Mangrara Banua Tongkonan adalah makna konotatif dan makna denotatif.
\end{abstract}

Kata Kunci: Masyarakat; Budaya; Mangrara Banua. 


\section{Nur Riswandy Marsuki, Lukman Ismail, Sam'un Mukramin. Upacara Mangrara Banua Tongkonan dalam Makna Sosial Masyarakat Tana Toraja}

\section{PENDAHULUAN}

Salah satu budaya di Indonesia yang sangat dikagumi adalah budaya Masyarakat Tana Toraja oleh karena itu harus selalu dijaga kelestariannya agar tidak punah dan terus menjadi wisata baik dari mancanegara maupun dalam negara. keununikan budaya Tana Toraja memang banyak dikagumi oleh masyarat, salah satu dari budaya uniknya adalah tradisi upacara Mangrara Banua Tongkonan yang selalu di nanti-nati kemeriahannya oleh masyarakat. Sam'un Mukramin (2015:417), Keterbatasan kemampuan atau daya piker tidak sedikit diantara manusia memilih sebuah pekerjaan untuk dilakukan bukan karena hasil akan tetapi proses yang diinginkan sebaliknya, tidak sedikit juga keberadaan manusia dalam mengenai pekerjaan tidak mengharapkan proses akan tetapi hasil yang kemudian menjadi sebagai tujuan utama dalam melakukan sebuah pekerjaan.

Hasil ini menunjukkan usaha masyarakat Tana Toraja dalam pelestarian upacara mangrara banua tongkonan yaitu dengan mengadakan upacara setiap masyarakat yang menbangun rumah tongkonan atau ketika upacara penggantian atap dan tiang. Upacara ini dilakukan dengan meriah dengan berbagai ritual yang ada. Dan semua masyarakat setempat ikut serta dalam upacara tersebut dan berpartisipasi dalam memeriahkan. partisipasi yang dapat diberikan masyarakat dalam suatu acara keudayaannya yaitu pasrtisipasi uang , partisipasi sosial, partisipasi dalam proses pengambilan keputusan, dan partisipasi representatif.Partispasi uang dsini dimaksudkan apabila setiap melakukan Upacara Mangrara Banua Tongkonan dapat menghabiskan banyak uang. Maka setia masyarakat harus saling memberikan sumbangan berupa uang atau menyumbangkan hewan ternaknya seperti Babi dan kerbau pada saat melakukan Upacara Mangra Banua Tongkonan.

Partisipasi tenaga dapat kita lihat dalam hal Keikutsertaan masyarakat dalam melaksanakan upacara dapat dilihat ketika melakukan penyembelihan hewan . mereka berarak arakan dengan cara membentuk lingkaran dan diringi musik tradisional dan taritarian sambil menyanyikan lag-lagu khas Tana Toraja. Selain itu juga ada partispasi sosial , pasrtisipasi ini seperti misalnya mengahdiri upacara kematian dan upacara peresmian rumah tongkonan berupa sumbangan perhatian atau tanda kedekatan dalam rangka memotivasi orang lain dalam berpartisipasi. Partisipasi dalam masyarakat dipengaruhi oleh faktor-faktor seperti pendidkan, pekerjaan, penghasilan,lamanya tinggal,iklin, eekonomi, budaya, sekolah maupun masyarakat dan bangsa yang menguntungkan serta mendorong tumbuh dan berkembang partispasi masyarakat dala melestarikan kebudayaannya.

Pemerintah dan masyarakat harus bekerjasama dalam menjaga kelestarian budaya agar tidak punah dan tetap menjadi budaya yang unik dan di kagumi oelh masyarakat. Selain itu tujuan yang ingin dicapai oleh masyarakat harus dibantu oleh norma-norma yang dimiliki dan sanksi terhadap nilai dan norma. Seperti ketika ada masyarakat yang tidak ikut serta dalam memeriahkan acara upacara tersebut maka akan dikucilkan oleh masyarakat karena dianggap tidak berpartisipasi dala hal kebersamaan. Apabila ada yang melanggar nilai dan aturan yang sudah ditentukan maka akan dikucilkan.

Parson (Sztompka, 2011), meyakini bahwa perkembangan masyarakat berkaitan dengan perkembangan keempat unsur subsistem utama: kultural (pendidikan), kehakiman (integrasi), pemerintahan (pencapaian tujuan), dan ekonomi (adaptasi). Masing-masing subsistem secara otonom, subkolektif-subkolektif. Dalam konteks ini, kemampuan adaptasi terhadap lingkungan merupakan tolak ukur dari tingkat otonominya. Kian adaptif berarti kian tinggi otonominya. Konkretnya, semakin tinggi otonomi masingmasing subkolektif dalam melakukan fungsi utamanya dalam rangka fungsi interpedensi sistem secara keseluruhan-semakin besar pula kemampuanya menyesuaikan diri terhadap lingkunganya, dan ini berarti semakin maju masyarkat yang bersangkutan.

Masyarakat tradisional adalah masyarakat yang menjunjung tinggi leluhurnya dan memegang teguh adat istiadatnya. Pada umumnya masyarakat tradisional adalam masyarakat yang memiliki pandangan bahwa melaksanakan warisan nenek moyangnya yang berupa nilai-nilai hidup, norma, harapan, citacita, merupakan kewajiban, kebutuhan, dan kebanggaan. Melaksanakan tradisi leluhur berarti menjaga keharmonisan masyarakat, namun sebaliknya melanggar tradisi berarti dapat merusak keharmonisan masyarakat.Maka dari itu masyarakat tradisional cenderung 


\section{Nur Riswandy Marsuki, Lukman Ismail, Sam'un Mukramin. Upacara Mangrara Banua Tongkonan dalam Makna Sosial Masyarakat Tana Toraja}

bersikap tertutup dan menaruh curiga terhadap unsur-unsur budaya asing, karena dianggap dapat merusak keharmonisan hubungan diantara sesama warga masyarakat.

Pendekatan yang digunakan dalam penelitian ini adalah teori struktural fungsionalisme dan teori interaksionisme simbolik. Pertimbangan memilih pendekatan ini karena teori ini memusatkan penelitian atau penjelasan pada hubungan antara manusia dengan Agama atau sistem kepercayaan dan kebudayaannya. Oleh karena itu untuk lebih memahami maka terlebih dahulu menjelaskan tentang teori struktural fungsionalisme. Teori Struktural fungsionalisme memandang agama sebagai salah satu lembaga sosial yang memegang kunci penting untuk menjawab kebutuhan mendasar dari masyarakat, jelasnya kebutuhan manusia yang tidak dapat dipuaskan dengan nilai-nilai duniawi yang serba sementara. Pandangan Weber (Betty R. Scharf, 1995 : 177-178) bahwa fungsi agama merupakan penolakan terhadap tradisi atau perubahan yang sangat cepat dalam metode dan evaluasi terhadap kegiatan ekonomi tidak akan mungkin terjadi tanpa dorongan dari moral dan agama.

Olehnya itu perlu kesadaran untuk tetap menjaga kelestarian budaya lokal. Karena dalam masyarakat pasti ada sistem kepercayaan atau agama yang diyakini masing-masing yang dapat menguatkan sistem kekerabatan seperti dalam upacara mangrara banua tongkonan yang dilakukan dengan meriah. Upacara ini dilakukan untuk meningkatkan ketakwaan pada Agama nya dan menghargai warisan leluhur. Dalam menjaga kelestarian lingkungan perlu melakukan pendekatan seperti pendekatan sosiologi yang menitikberatkan perhatiannya pada masyarakat. Dalam hal ini masyarakat berfungsi sebagai pemelihara kebudayaan. Masyarakat dipandang sebagi bagian dari kebudayaan. Tanpa masyarakat maka kebudayaan tidak akan berjalan begitupun sebaliknya.

Kemudian teori Interaksionisme simbolik, dimana teori ini sangata berhubungan denga makna-makna yang disampaikan dari setiap Upacara yang dilakukan seperti pada upacara mangrara banua tongkonan di Tana Toraja. Dari kata interasi berarti masyarakat dalam kehidupannya sehari-hari akan selalu berinteraksi dengan makhluk lainnya, seperti dengan makhluk sosial lainnya atau masyarakat itu sendiri atau berinteraksi dengan hewan, tumbuhan. Yang tidak kala pentingnya adalah berinteraksi dengan Tuhan dan roh nenek moyang, seperti yang dilakukan oleh masyarakat Tana Toraja dalam Upacara Mangrara Banua Tongkonan.

Teori interaksionisme simbolik memandang bahwa kehidupan sosial pada dasarnya adalah interaksi manusia yang menggunakan simbol-simbol yang mempresentasikan apa yang mereka maksudkan untuk berkomunikasi dengan sesamanya. Perspektif Interaksionisme Simbolik sering dikelompokkan menjadi 2 aliran (school) (Sobur 2004;200), yakni: Chicago school yang dimotori oleh Herbert Blummer dengan berpedoman pada ajaran george Herbert Mead dan Lowa school yang dimotori oleh Manford H. Kunh dan Carl Couch.Meskipun sama-sama menganut teori interaksionisme Simbolik, namun terdapat banyak perbedaan pendapat diantara kedua aliran tersebut.Jika Blummer menjurus pada pemaknaan idiografi dan mengkritik metodologi kuantitatif sebagai gagal menangkap makna, maka Khun mengarah ke pencarian standarisasi dan objektivitas serta mentransformasikan interaksionisme simbolik kedalam variabelvariabel (Sobur 2004;201).

Dari pernyataan kedua etori tersebut sama-sama membahas tentang interaksi manusia dengan Agama dan kepercayaanya. Berdasarkan kajian teori diatas, dalam hal pelaksanaan Upacara Mangrara Banua Tongkonan di tana toraja memberikan makna simbolik seperti rumah adat yang berbentuk tanduk kerbau dan terdapat tanduk kerbau sebagai simbol bahwa telah dilaksanakan Upacara Mangrara Banua Tongkonan.

\section{METODE PENELITIAN}

Menurut Sugiyono (2013) metode kualitatif adalah metode penelitian yang digunakan untuk meneliti pada objek alamiah yang mana peneliti adalah sebagai instrumen kunci. Artinya, penelitian dilakukan untuk memperoleh informasi tentang status gejala saat penelitian dilakukan atau dengan kata lain meneliti objek tujuan secara alamiah dan peneliti adalah sebagai instrument kunci. Penelitian yang menekankan pada peristiwa pada kelompok, sistem pemikiran termasuk hubungan kegiatan- 
kegiatan, sikap-sikap, pandangan pandangan atau partisipasi masyarakat dalam melestarikan budaya upacara mangarara banua tongkonan di tana Toraja. Hal tersebut bertujuan untuk menggambarkan sesuatu yang akurat tentang fakta-fakta serta hubungan antar fenomena yang diteliti.

Dalam hal ini fenomena yang diteliti berkaitan Makna sosiIal upacara mangrara banua tongkonan. Pada penelitian di lapangan peneliti menggali suatu fenomena sosial yaitu faktor penyebab masih dilestarikannya upacara mangrara banua tongkonan. Peneliti melihat fenomena tersebut dari fakta-fakta sosial yang teramati sehingga pada dasarnya begitu komplek. Partisipasi masyarakat dalam melestarikan upacara mangrara banua tongkonan yang melibatkan berbagai lapisan sosial dalam masyarakat membutuhkan analisis kualitatif yang lebih menekankan pada fakta yang teramati dan menggali fakta dibalik fakta yang teramati.

Dalam hal ini tentunya fakta-fakta yang berkaitan dengan partisipasi masyarakat dalam melestarikan tradisi upacara mangrara banua tongkonan, Penelitian ini di laksanakan di kabupaten Tana Toraja. Pemilihan lokasi tersebut dengan alasan bahwa nilai dan tradisi yang di anut oleh masyarakat Tana Toraja masih kental dan masih terjaga keunikannya nya sampai sekarang. Dan masyarakat senantiasa melestarikan budayanya denga melakukan berbagai ritual yang ada. Hal ini terlihat dari partisipasi masyarakatnya yang masih menjalankan tradisi tersebut.

\section{HASIL DAN PEMBAHASAN}

Pelaksanaan Upacara Mangrara Banua Tongkonan di Tana Toraja sudah menjadi tradisi setiap warga. Sebelum datangnya agama Kristen dan islam, suku Toraja menganut agama dari nenek moyang yang mereka warisi secara turun temurun . warisan inilah yang dianggap sebagai agama dan kepercayaan asli yang terkenal dengan sebutan aluk todolo. Aluk Todolo inilah yang mendasari sendi sendi kehidupan masyarakat Toraja ,termasuk adat istiadatnya. Kepercayaan Aluk Todolo ini diyakini sama tuanya dengan nenek manusia yang pertama yaitu Datu La Ukku'. Keturuna Datu La Ukku' inilah yang pertama kali di utus di bumi salah satu keturunannya yang bernama pong mula au yang turun dari langit membawa ajaran untuk mengadakan pemujaan/persembahan kepada puang matua.

Ajaran Aluk Todolo mengemukakan bahwa diluar diri manusia terdapat tiga unsur kekuatan yang wajib untuk dipercaya oleh karena kekuatan yang wajib untuk dipercaya. Upacara adat tradisional masyarakat merupakan perwujudan dari sistem kepercayaan masyarakat yang mempunyai nilai-nilai universal yang dapat menunjang kebudayaan nasuonal.Upacara tradisional ini bersifat kepercayaan dan dianggap sakral dan suci. Dimana setiap aktifitas manusia selalu mempunyai maksud dan tujuan yang ingin dicapai, termasuk kegiatan-kegiatan yang bersifat religious. Mangrara Banua atau biasa disebut dengan mensucikan rumah adat dengan darah hewan adalah salah satu upacara adat yang rutin dilakukan oleh masyarakat Tana Toraja pada saat meresmikan rumah (Tongkonan) sebelum ditinggali.

Fungsi dari Upacara Mangrara Banua Tongkonan adalah untuk meresmikan rumah (Tongkonan) sebelum ditinggali. Dimulai oleh sambutan dari pemuka adat, upacara dilanjutkan dengan tari-tarian oleh para wanita Toraja yang diiringi dengan tabuhan gendang. Para penonton dari berbagai kalangan baik turis domestik maupun mancanegara pun tak berdiam diri. Mereka ikut menari untuk memeriahkan upacara Mangrara Buana ini.

Dalam masyarakat Tana Toraja sangat menjunjung tinggi sistem kepercayaan yang dianut dari ajaran Aluk todolo yang sudah menjadi tradisi dari setiap warga. Dalam Upacara tersebut terdapat berbagai ritual yang memberikan makna tersendiri.

“...Koentjaraningrat, (1989: 72) berpendapat bahwa dalam melakukan aktifitasnya manusia mempunyai aturan-aturan yang dijadikannya sebagai pedoman dalam bertingkah laku, dimana pedoman tersebut adalah kebudayaan. Kebudayaan itu sendiri merupakan keseluruhan sistem gagasan, ide, rasa, tindakan serta karya yang dihasilkan oleh manusia dalam kehidupan bermasyarakat yang dijadikan miliknya melalui belajar...".

Faktor penyebab Upacara Mangrara Banua Tongkonan masih dilestarikan sampai sekarang karena adanya nilai, tradisi dan partisispasi masyarakat, untuk lebih dipahami maka perlu dijelaskan tentang apa itu nilai, tardisi, dan 
pertisipasi masyarakat dalam pelestarian upacara ini :

\section{Nilai}

Nilai adalah kualitas perilaku, pikiran dan karakter yang dianggap masyarakat baik dan benar yang layak ditiru oleh setiap orang. Dalam masyarakat nilai sangat dijunjung tinggi dan dihargai karena dapat memberikan penghargaan dan sebagai kualitas diri masyarakat. Seperti yang ada di Tana Toraja, mereka beranggapan bahwa ketika kita menghargai warisan leluhur dengan melakukan upacara penghormatan terhadap leluhur maka masyarakat tersebut dianggap sudah melaksanakan kewajibannya dan menandakan orang tersebut akan mendapatkan kesejahteraan seperti mendapatkan rejeki dan terhindar dari malapetaka.

\section{Tradisi}

Tradisi adalah suatu gambaran sikap dan perilaku manusia yang telah berproses dalam waktu lama dan dilakukan secara turun-temurun dimulai dari nenek moyang. Tradisi yang telah membudaya akan menjadi sumber dalam berakhlak dan berbudi pekerti seseorang. Sebelum memaparkan tentang pelestarian Upacara Mangrara Banua Tongkonan terlebih dahulu menjelaskan apa yang dimaksud dengan Upacara Mangrara Banua Tongkonan.

Upacara adat tradisional masyarakat merupakan perwujudan dari sistem kepercayaan masyarakat yang mempunyai nilai-nilai universal yang dapat menunjang kebudayaan nasuonal.Upacara tradisional ini bersifat kepercayaan dan dianggap sakral dan suci. Dimana setiap aktifitas manusia selalu mempunyai maksud dan tujuan yang ingin dicapai, termasuk kegiatan-kegiatan yang bersifat religious. Mangrara Banua atau biasa disebut dengan mensucikan rumah adat dengan darah hewan adalah salah satu upacara adat yang rutin dilakukan oleh masyarakat Tana Toraja pada saat meresmikan rumah (Tongkonan) sebelum ditinggali. Fungsi dari Upacara Mangrara Banua Tongkonan adalah untuk meresmikan rumah (Tongkonan) sebelum ditinggali. Dimulai oleh sambutan dari pemuka adat, upacara dilanjutkan dengan tari-tarian oleh para wanita Toraja yang diiringi dengan tabuhan gendang. Para penonton dari berbagai kalangan baik turis domestik maupun mancanegara pun tak berdiam diri. Mereka ikut menari untuk memeriahkan upacara Mangrara Buana ini.

\section{Partisipasi masyarakat}

Partispasi adalah keterlibatan aktif dari sesorang, atau sekelompok orang (masyarakat) secara sadar untuk berkontribusi secara sukarela dalam program pembangunan dan terlibat mulai dari perencanaan,pelaksanaan sampai pada tahap evaluasi.pentingnya berpartisipasi dalam masyarakat terutma dalam bidang kebudayaan suatu alat guna untuk mengetahui kondisi, kebutuhan, dan sikap masyarakat setempat, kerena mereka akan lebih mengetahui seluk beluk proyek tersebut dan akan mempunyai rasa memiliki terhadap kebudayaannya. Apa yanh inigin dicapai dalam partisipasi masyarakat adalah untuk melestarikan kebudayaannya. Dengan cara Masyarakat harus terlibat dalam hal pelaksanaan dan pengambilan keputusan.

Ada beberapa bentuk partisipasi yang dapat diberikan masyarakat dalam suatu acara keudayaannya yaitu pasrtisipasi uang, partisipasi sosial, partisipasi dalam proses pengambilan keputusan, dan partisipasi representatif.Partispasi uang dsini dimaksudkan apabila setiap melakukan upacara Mangrara Banua Tongkonan dapat menghabiskan banyak uang. Maka setia masyarakat harus saling memberikan sumbangan berupa uang atau menyumbangkan hewan ternaknya seperti Babi dan kerbau pada saat melakukan Upacara Mangra Banua Tongkonan.

Partisipasi tenaga dapat kita lihat dalam hal keikutsertaan masyarakat dalam melaksanakan upacara dapat dilihat ketika melakukan penyembelihan hewan mereka berarak arakan dengan cara membentuk lingkaran dan diringi musik tradisional dan tari-tarian sambil menyanyikan lag-lagu khas Tana Toraja. Selain itu juga ada partispasi sosial, pastisipasi ini seperti misalnya mengahdiri upacara kematian dan upacara peresmian rumah tongkonan berupa sumbangan perhatian atau tanda kedekatan dalam rangka memotivasi orang lain dalam berpartisipasi.

Dalam melestarikan upacara Mangrara Вапиа ini perlu adanya partisipasi dari masyrakat dan kesadaran akan kepercayaan yang dianut oelh masyarakat. Dimana kepercayaan mereka adalah ajaran aluk todolo yaitu ajaran yang diwariskan oleh para leluhur yang telah mendahului. Yang apabila tidak dilakukan maka masyarakat tidak akan hidup dengan damai didunia dan akan mendapatkan mala petak. 


\section{Nur Riswandy Marsuki, Lukman Ismail, Sam'un Mukramin. Upacara Mangrara Banua Tongkonan dalam Makna Sosial Masyarakat Tana Toraja}

Mangrara Banua atau biasa disebut dengan mensucikan rumah adat dengan darah hewan adalah salah satu upacara adat yang rutin dilakukan oleh masyarakat Tana Toraja pada saat meresmikan rumah (Tongkonan) sebelum ditinggali. Salah satu daerah disulawesi selatan yang masih kental budayangnya adalah Kabupaten Tana Toraja yang kaya akan budayanya yang unik dan menari perhatian masyarakat indonesi maupun mancanegara. Tongkonan pada dasarnya adalah sebuah rumah kayu yang dibangun oleh masyarakat Tanah Toraja.Rumah panggung dari kayu tersebut dianggap penting oleh masyarakat Tana Toraja.

Selanjutnya wilayah Kabupaten tana Toraja yang masih melakukan upacara Mangrara Вапиа tongkonan adalah Kelurahan Ariang Kecamatan Makale yang setiap pelaksanaannya dilakukan dengan meriah setiap membangun rumah tongkonan maupun ketika penggantian atap dan tiang yang dihadiri oleh sema warga Kelurahan Ariang. Upacara dilakukan dengan berbagai ritual yang memiliki makna tersendiri. dalam suku Toraja. Setiap desa adalah suatu keluarga besar. Setiap tongkonan memiliki nama yang dijadikan sebagai nama desa. Keluarga ikut memelihara persatuan desa. Pernikahan dengan sepupu jauh (sepupu keempat dan seterusnya) adalah praktek umum yang memperkuat hubungan kekerabatan.Suku Toraja melarang pernikahan dengan sepupu dekat (sampai dengan sepupu ketiga) kecuali untuk bangsawan, untuk mencegah penyebaran harta.

Pada mulanya, sifat geografis Tana Toraja yang terisolasi membentuk banyak dialek dalam bahasa Toraja itu sendiri. Setelah adanya pemerintahan resmi di Tana Toraja, beberapa dialek Toraja menjadi terpengaruh oleh bahasa lain melalui proses transmigrasi, yang diperkenalkan sejak masa penjajahan. Hal itu adalah penyebab utama dari keragaman dalam bahasa Toraja. Ciri yang menonjol dalam bahasa Toraja adalah gagasan tentang duka cita kematian. Pentingnya upacara kematian di Toraja telah membuat bahasa mereka dapat mengekspresikan perasaan duka cita dan proses berkabung dalam beberapa tingkatan yang rumit.

Bahasa Toraja mempunyai banyak istilah untuk menunjukkan kesedihan, kerinduan, depresi, dan tekanan mental. Merupakan suatu katarsis bagi orang Toraja apabila dapat secara jelas menunjukkan pengaruh dari peristiwa kehilangan seseorang; hal tersebut kadangkadang juga ditujukan untuk mengurangi penderitaan karena duka cita itu sendiri.

Makna adalah hubungan suatu objek dengan lambangnya. Makna pada dasarnya terbentuk berdasarkan hubungan antara lambang komunikasi (simbol), akal budi manusia penggunanya (obyek). Makna menurut kemampuan integratif manusia, yakni indrawinya, daya pikirnya dan akal budinya. Manusia adalah makhluk sosial yang dapat bergaul dengan dirinya sendiri, dan orang lain menafsirkan makna-makna obyek-obyek di alam kesadarannya dan memutuskannya bagaimana ia bertindak secara berarti sesuai dengan penafsiran itu. Bahkan seseorang melakukan sesuatu karena peran sosialnya atau karena kelas sosialnya atau karena sejarah hidupnya.

Makna Sosial dalam uapacara Mangrara Banua tongkonan adalah nilai atau sistem kepercayaan. Dengan adanya nilai dan sistem kepercayaan dalam masyarakat dapat meningkatkan kekuatan dalam diri masyarakat untuk menjaga dan melestarikan budayanya agar tetap dilaksanakan. Selain itu dalam diri setiap masyarakat harus menjunjung tinggi tradisi. Dimana tradisi adalah suatu gambaran sikap dan perilaku manusia yang telah berproses dalam waktu lama dan dilakukan secara turun-temurun dimulai dari nenek moyang. Tradisi yang telah membudaya akan menjadi sumber dalam berakhlak dan berbudi pekerti seseorang. Sebelum memaparkan tentang pelestarian upacara Mangrara Banua Tongkonan terlebih dahulu menjelaskan apa yang dimaksud dengan Upacara Mangrara Banua Tongkonan.

Upacara adat tradisional masyarakat merupakan perwujudan dari sistem kepercayaan masyarakat yang mempunyai nilai-nilai universal yang dapat menunjang kebudayaan nasuonal.Upacara tradisional ini bersifat kepercayaan dan dianggap sakral dan suci. Dimana setiap aktifitas manusia selalu mempunyai maksud dan tujuan yang ingin dicapai, termasuk kegiatan-kegiatan yang bersifat religious. Mangrara Вапиa atau biasa disebut dengan mensucikan rumah adat dengan darah hewan adalah salah satu upacara adat yang rutin dilakukan oleh masyarakat Tana Toraja pada saat meresmikan rumah (Tongkonan) sebelum ditinggali. Fungsi dari Upacara Mangrara Banua Tongkonan adalah untuk meresmikan rumah (Tongkonan) sebelum 
ditinggali. Dimulai oleh sambutan dari pemuka adat, upacara dilanjutkan dengan tari-tarian oleh para wanita Toraja yang diiringi dengan tabuhan gendang. Para penonton dari berbagai kalangan baik turis domestik maupun mancanegara pun tak berdiam diri. Mereka ikut menari untuk memeriahkan upacara Mangrara Buana ini.

\section{SIMPULAN DAN SARAN}

Berdasarkan hasil penelitian yang dilakukan mengenai faktor penyebab upacara mangrara banua masih dilestarikan karena adanya nilai,tradisi dan partisipasi masyarakat.

Berdasarkan hasil penelitian tentang Makna Sosial Upacara Mangrara Banua Tongkonan di Tana Toraja tentang makna yang terkandung dalam uapacara tersebut adalah makna konotatif dan denotatif. Dimana makna konotatif adalah makna yang berdasarkan nilai rasa sedangkan makna denotatif adalah makna yang berasal dari tndakannya sendiri dan tidak berdasarkan nilai rasa yang bersifat apa adanya.

\section{DAFTAR RUJUKAN}

Sam'un Mukramin. Jurnal Walasuji. Vol. 6, No. 2 Desember 2015: 413-424. Dengan judul: Pemulung sebagai Fenomena Sosial di TPA Sampah Tamangapa Kota Makassar.

Scharf, Betty R. (1995). Kajian Sosiologi Agama. Yokyakarta: PT. Tiara Wacana Yogya

Sobur, Alex. 2004. Semiotika Komunikasi. Bandung: Remaja Rosdakarya

Sztompka, Piötr. 2011. Sosiologi Perubahan Sosial. (Cetakan ke-6) Jakarta: Kencana Prenada Media Group.

Sugiyono. 2013. Metode Penelitian Pendidikan : Pendekatan Kuantitatif, Kualitatif, dan $R \& D$. Bandung : Penerbit Alfabeta
Panji,Yearry.2008. Teori Inreaksionisme Simbolik

http://Yearrypanji.Wordpress.com/2 008/03/17/teori-interaksionismesimbolik/

Koentjaraningrat. 1989. Kebudayaan Metalitas dan Pengembangan. Jakarta :Gramedia

Budhisantoso, Subur. 1989. Tradisi Lisan Sebagai Sumber

Informasi Kebudayaan Dalam Analisa Kebudayaan, Jakarta: Depdikbud. 